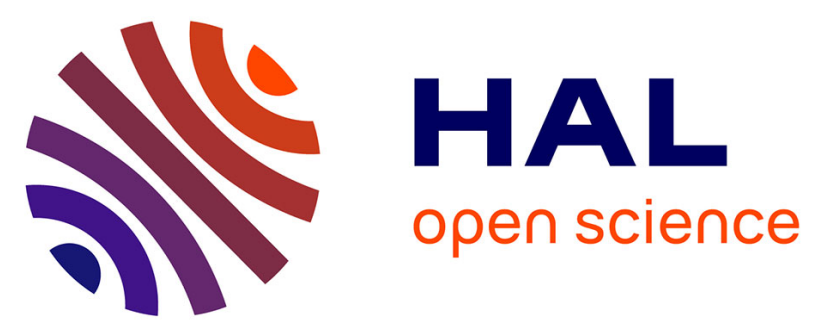

\title{
Males of the orchid bee Eulaema cingulata (Hymenoptera: Apidae) as important vectors of the cleptoparasitic beetle Meloetyphlus fuscatus (Coleoptera: Meloidae)
}

Léo Correia da Rocha-Filho, Carlos Alberto Garófalo

\section{To cite this version:}

Léo Correia da Rocha-Filho, Carlos Alberto Garófalo. Males of the orchid bee Eulaema cingulata (Hymenoptera: Apidae) as important vectors of the cleptoparasitic beetle Meloetyphlus fuscatus (Coleoptera: Meloidae). Apidologie, 2015, 46 (3), pp.286-291. 10.1007/s13592-014-0322-1. hal01284447

\section{HAL Id: hal-01284447 \\ https://hal.science/hal-01284447}

Submitted on 7 Mar 2016

HAL is a multi-disciplinary open access archive for the deposit and dissemination of scientific research documents, whether they are published or not. The documents may come from teaching and research institutions in France or abroad, or from public or private research centers.
L'archive ouverte pluridisciplinaire HAL, est destinée au dépôt et à la diffusion de documents scientifiques de niveau recherche, publiés ou non, émanant des établissements d'enseignement et de recherche français ou étrangers, des laboratoires publics ou privés. 


\title{
Males of the orchid bee Eulaema cingulata (Hymenoptera: Apidae) as important vectors of the cleptoparasitic beetle Meloetyphlus fuscatus (Coleoptera: Meloidae)
}

\author{
Léo Correia da Rocha-FiLho ${ }^{1}$, Carlos Alberto GARÓFALO ${ }^{2}$ \\ ${ }^{1}$ Department of Biology, York University, Toronto, Ontario M3J 1P3, Canada \\ ${ }^{2}$ Departamento de Biologia, Fac. de Filosofia, Ciências e Letras de Ribeirão Preto-FFCLRP, Universidade de São Paulo- \\ USP, Ribeirão Preto, São Paulo 14040-901, Brazil
}

Received 11 July 2014 - Revised 4 September 2014 - Accepted 24 September 2014

\begin{abstract}
Meloid beetles are known by their hypermetamorphic life cycle with active first instar larvae called triungulins found in most species. Most of the larvae in this family feed on provisions and immature stages of bees. The monotypic genus Meloetyphlus is associated with the nests of some orchid bee species, and some of its morphological characteristics suggest the adults live only in the host nest. In an orchid bee survey carried out in Ubatuba, São Paulo State, Brazil, 1575 specimens of 23 species of euglossine bees were collected. Of this total, 170 $(10.8 \%)$ specimens of six species, mostly males, had triungulin larvae of Meloetyphlus fuscatus attached to their bodies. The highest percentage of infestation was found in Eulaema cingulata, with $79.8 \%$ of males carrying beetle larvae. The implications of these data are discussed, and the association of M. fuscatus with four species of orchid bees (Eufriesea dentilabris, Eulaema helvola, Eulaema seabrai and Exaerete smaragdina) is reported for the first time.
\end{abstract}

Euglossini / parasitism / triungulins

\section{INTRODUCTION}

The family Meloidae is represented by nearly 120 genera and 2500 species distributed throughout the world except for some small oceanic islands, New Zealand and Antarctica (Pinto and Bologna 1999; Bologna and Pinto 2001; Bologna and Di Giulio 2011). These beetles are known by their hypermetamorphic life cycle involving, in most taxa, an active and well-sclerotized first instar larva called a triungulin (Selander and Mathieu 1964; Selander 1991). The active triungulin larvae of species of the tribes Epicautini and most Mylabrini seek out eggs of Acridoidea as a food source, but most meloid

Corresponding author: L. Rocha-Filho, correiadarocha@yahoo.com.br

Manuscript Editor: Klaus Hartfelder species feed on the provisions and immature stages of aculeate Hymenoptera, mostly bees (Bologna and Di Giulio 2011). Some meloid females lay their eggs on flowers where the triungulins can easily access a bee to be transported to the host nest (Erickson et al. 1976; Packer 1987). Others lay the eggs in the ground, and the triungulins have to locate a suitable site from which to find a host (Selander 1960), sometimes attracting the bees through pheromone mimicry (Saul-Gershenz and Millar 2006; Vereecken and Mahé 2007). However, in species of the genera Cissites Latreille, Hornia Riley, and Meloetyphlus Waterhouse, the eggs are placed near or inside the host nest (Bianchi 1962; Linsley et al. 1980; Garófalo et al. 2011).

The genus Meloetyphlus is monotypic, and the single species Meloetyphlus fuscatus Waterhouse has been recorded as a parasite of different species of orchid bees (Euglossini): Eufriesea 
smaragdina (Perty), Eulaema cingulata (Fabricius), Eulaema meriana (Olivier), Eulaema nigrita Lepeletier, Eulaema terminata Smith and maybe Eufriesea violacea (Blanchard) and Eulaema polychroma (Mocsáry) (Horn 1928; Bennett 1965; Dodson 1966; Santos and Garófalo 1994; Peruquetti and Campos 1997; Nates-Parra and González 2000; Cameron and Ramírez 2001; Garófalo et al. 2011). Some characteristics of adults of this species, such as the lack of compound eyes and functional wings, the weakly melanized integument, and some evidence that they may be aphagous (Selander 1965), suggest that they remain within the host nest. Recently, the biology of the genus was studied by Garófalo et al. (2011) from nests of E. nigrita. The authors reported oviposition in the nest and no food consumption by adults, supporting the view that the adult is adapted to live within the host nest as first suggested by Selander (1965). After emergence from the egg, the triungulin larvae disperse from the host nest by phoresy by attaching to the body of male host bees (Garófalo et al. 2011). After leaving the nests, male bees carrying the triungulins then may transfer the parasites to females during mating thereby facilitating entry to a suitable brood cell. Thus, Eulaema males may play an important role as vectors of $M$. fuscatus larvae.

During a survey of orchid bees in two ecosystems of Atlantic forest in Southeastern Brazil (Rocha-Filho and Garófalo 2013), triungulin larvae of $M$. fuscatus were recorded from six potential host species, mainly from males of $E$. cingulata. The association of $M$. fuscatus with four species of Euglossini is presented herein for the first time, and the role of E. cingulata males as vectors of this cleptoparasitic beetle is discussed.

\section{MATERIAL AND METHODS}

Orchid bee males were sampled using scent baits monthly at two sites, 'Parque Estadual da Serra do Mar-PESM' in the Picinguaba region (44 $49^{\prime}-44^{\circ}$ $50^{\prime} \mathrm{W}$ and $23^{\circ} 21^{\prime} \mathrm{S}$ ) and 'Parque Estadual da Ilha Anchieta-PEIA' on Anchieta Island ( $45^{\circ} 02^{\prime}-45^{\circ} 05^{\prime}$ $\mathrm{W}$ and $23^{\circ} 31^{\prime}-23^{\circ} 34^{\prime} \mathrm{S}$ ) from August 2007 to July 2009 in Ubatuba, São Paulo State, Brazil. The local climate has two distinct seasons: a hot and superhumid season from October to April and a cool and less-humid season from May to September (for details, see Rocha-Filho and Garófalo 2013). Males and females were also observed on flowers near the study sites, and females collecting clay or resin to build their nests as well as cleptoparasitic females of seeking nests to attack were also collected. All specimens collected were stored in vials with $96 \%$ ethyl alcohol. If triungulin larvae were recorded on a given individual, they were separated, counted, and stored in $70 \%$ ethyl alcohol for study.

\section{RESULTS}

A total of 1575 bees of 23 species were sampled in 2 years. Of all bees recorded, 170 (10.8\%) individuals belonging to six species had triungulin larvae attached to their body: Eufriesea dentilabris (Mocsáry), E. cingulata, Eulaema helvola Moure, E. nigrita, E. seabrai Moure, and Exaerete smaragdina (Guérin) (Table I). The associations of triungulin larvae of M. fuscatus with E. dentilabris, E. helvola, E. seabrai, and Ex. smaragdina are reported here for the first time. Of the 170 bees with triungulins, 158 were males of $E$. cingulata, 115 of which had been collected in Picinguaba, the remaining 43 were sampled from the Anchieta Island. In Picinguaba, except for February 2008 when no E. cingulata male was attracted to the chemical baits, males with triungulin larvae were collected in all months of the study period. The percentage of infested males per month ranged from $0(n=2$ cases) to $100 \%$ ( $n=8$ cases) (Figure 1$)$, and the number of triungulin larvae attached to the males ( $n=3242$ triungulins) varied from 1 to $437(\bar{x}=$ $27.59 \pm 62.41$ ) (Figure 2). On Anchieta Island, males with triungulins were found in 14 of the 24 samples with the proportion of males with triungulins ranging from 0 ( $n=4$ cases) to $100 \%$ ( $n=9$ cases) (Figure 1), and the number of triungulins found ( $n=1287$ triungulins) ranged from 1 to 275 ( $\bar{x}=31.12 \pm 60.52$ ) (Figure 2). In both sites, a small number of males had more than 190 triungulins, but most had less than 90 attached to their bodies (Figure 2). 
Table I. Orchid bees collected in Ubatuba, São Paulo, Brazil, from August 2007 to July 2009 and infested by triungulin larvae of Meloetyphlus fuscatus .

\begin{tabular}{lllcl}
\hline Orchid bee species & TS & TI & $\%$ & Gender \\
\hline Eufriesea dentilabris (Mocsáry, 1897) & 14 & 1 & 7.1 & 1 female \\
Eulaema cingulata (Fabricius, 1804) & 198 & 158 & 79.8 & 158 males \\
Eulaema helvola Moure, 2003 & 7 & 1 & 14.3 & 1 male \\
Eulaema nigrita Lepeletier, 1841 & 27 & 5 & 18.5 & 5 males \\
Eulaema seabrai Moure, 1960 & 52 & 3 & 5.8 & 2 females; 1 male \\
Exaerete smaragdina (Guérin, 1844) & 4 & 2 & 50 & 2 males \\
Total & 302 & 170 & - & 3 females; 167 males \\
\hline
\end{tabular}

TS total \# of bees sampled, TI total \# of bees infested by triungulin larvae.

\section{DISCUSSION}

The association of M. fuscatus and Eufriesea spp. was first reported by Horn (1928) from two pairs of the cleptoparasitic beetle that emerged from a nest of Ef. smaragdina built in bamboo canes in Costa Rica. The other record was published by Peruquetti and Campos (1997) who collected specimens of Meloetyphlus from two nests of E. violacea in Brazil. However, most of the host association of $M$. fuscatus have been recorded from Eulaema spp. nests (Bennett 1965; Dodson 1966; Santos and Garófalo 1994; Nates-Parra and González 2000; Cameron and Ramírez 2001; Garófalo et al. 2011). In the present study, only one of the seven species of Eufriesea sampled in Ubatuba (Rocha-Filho and Garófalo 2013) was associated with M. fuscatus

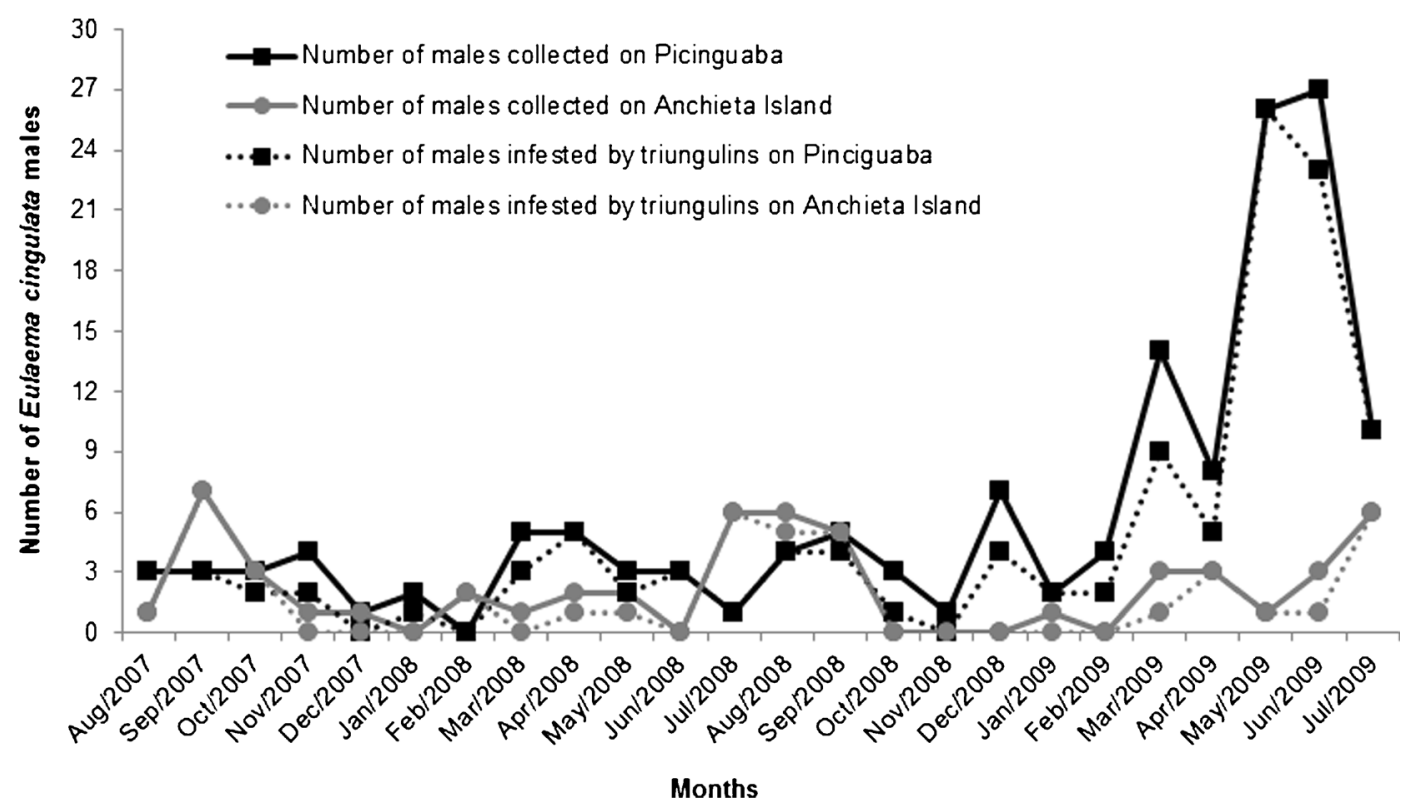

Figure 1. Number of Eulaema cingulata males collected monthly and number of males infested by first instar larvae (triungulins) of Meloetyphlus fuscatus in Picinguaba and Anchieta Island, Ubatuba, São Paulo, Brazil, from August/2007 to July/2009. 


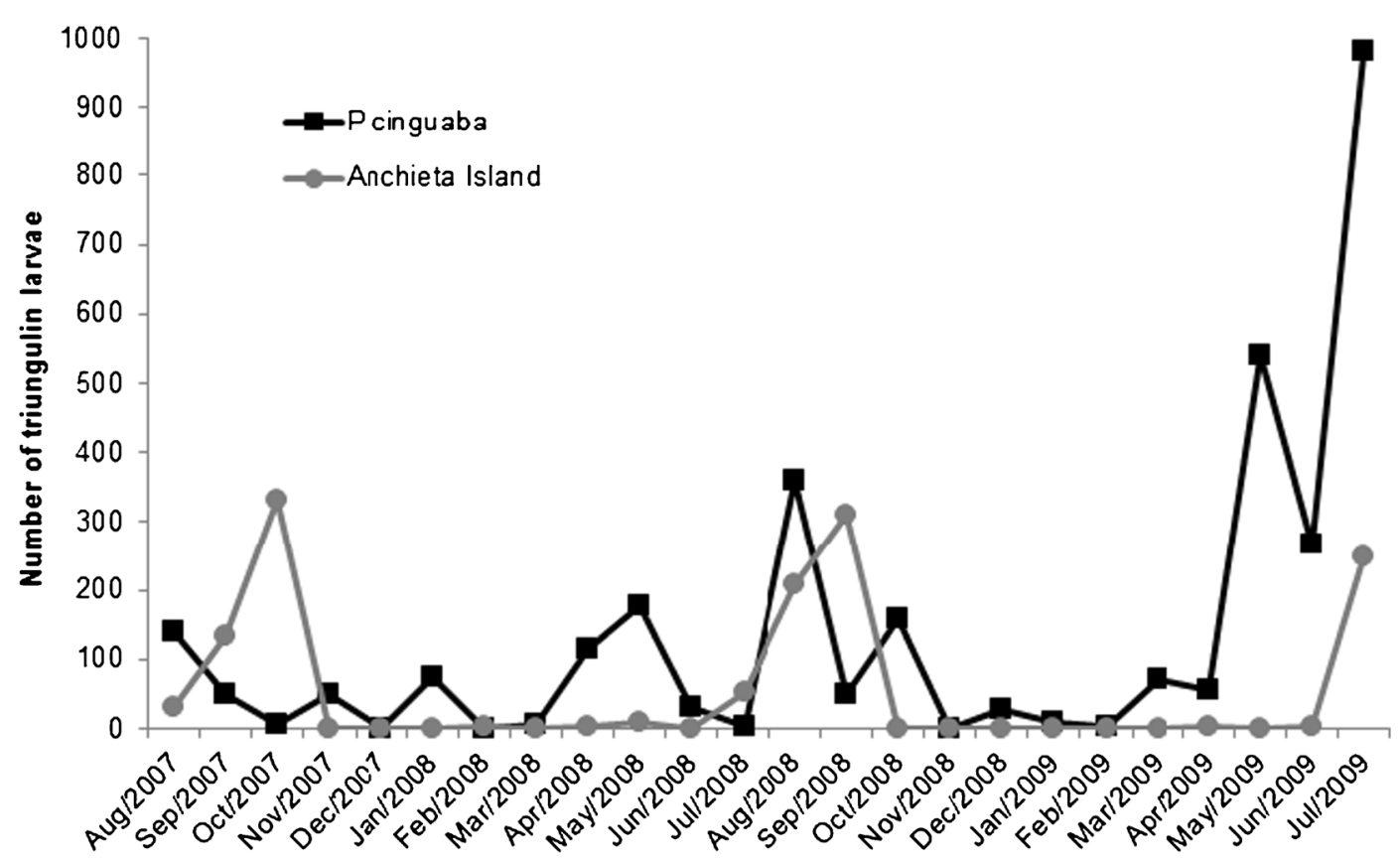

Months

Figure 2. Number of first instar larvae (triungulins) of Meloetyphlus fuscatus attached to the body of Eulaema cingulata males collected monthly in Picinguaba and Anchieta Island, Ubatuba, São Paulo, Brazil, from August/ 2007 to July/2009.

whereas specimens from all four species of Eulaema recorded at the same sites had triungulin larvae of this beetle attached to their bodies. Triungulin larvae were also collected from males of Ex. smaragdina, a cleptoparasite of E. nigrita nests (Garófalo and Rozen 2001). Considering this fact, this cleptoparasitic bee can cause mortality of host immature stages either directly by parasitizing the brood cells or indirectly by transporting the larvae of another natural enemy, the meloid. In the last case, as suggested by Garófalo et al. (2011), the triungulin will have to seek a cell that is being provisioned and stay there until the host female finishes the provisioning and oviposit in it. Nevertheless, as occurs with triungulins being carried by Eulaema males, the triungulins must be transferred to Exaerete females during mating since the latter search for host nests to parasitize (Garófalo et al. 2011).

In spite of the low parasitism rate by $M$. fuscatus in E. cingulata nests, Dodson (1966) reported that several specimens of this bee species were infested by triungulin larvae. In Ubatuba, $80 \%$ of E. cingulata males contained triungulins attached to their bodies; the highest percentage of any of the bees surveyed that were carrying the beetle larvae.

The occurrence of infested male E. cingulata throughout the study period in Picinguaba and in 14 of the 24 samples collected in Anchieta Island suggest that host nests in the study areas suffer intense parasitism by M. fuscatus. The other three Eulaema species sampled had relatively low incidences of parasitism. These differences in the percentages of infestation may be related to the abundance of males that indirectly suggests higher frequency of nesting by E. cingulata. Thus, the higher the number of nests in the area, the higher the probability that the nest will be parasitized and the parasitism will be maintained throughout generations.

As previously reported (Garófalo et al. 2011), the number of triungulins being carried by a male was very variable. Garófalo et al. (2011) found 
that the first male bees to emerge within a nest parasitized by M. fuscatus will transport the largest number of triungulins while the later males carry few. Interestingly, males of E. cingulata with the largest numbers of triungulins attached to their bodies were collected in months with the greatest abundance of males attracted to our chemical baits. This reinforces the idea that the peaks of collecting males in the field reflect the occurrence of individuals emerging from the nests established in the area.

\section{ACKNOWLEDGMENTS}

The authors are grateful to the staff at the study sites (PESM and PEIA) for their support and to the "Conselho Nacional de Desenvolvimento Científico e Tecnológico" (CNPq; grant no. 141022/2007-8) for providing a scholarship to the first author and the "Fundação de Amparo à Pesquisa do Estado de São Paulo" (FAPESP; grant no. 04/15801-0) for financing some of our collecting trips.

\begin{abstract}
Mâles de l'abeille à orchidée Eulaema cingulata (Hymenoptera:Apidae), importants vecteurs du coléoptère cleptoparasite Meloetyphlus fuscatus (Coleoptera: Meloidae)
\end{abstract}

\section{Euglossini / relation hôte parasite / larve trionguline}

Die Männchen der Prachtbiene Eulaema cingulata (Hymenoptera: Apidae) sind wichtige Vektoren für die Verbreitung des kleptopartasitischen Käfers Meloetyphlus fuscatus (Coleoptera: Meloidae)

\section{Euglossini / Parasitismus / Triungulinen Larven}

\section{REFERENCES}

Bennett, F.D. (1965) Notes on a nest of Eulaema terminata Smith (Hymenoptera, Apoidea) with a suggestion of the occurrence of a primitive social system. Insectes Soc. 12, 81-92

Bianchi, F.A. (1962) Notes on the biology of Cissites auriculata (Champion) (Coleoptera: Meloidae). Proc. Hawaii. Entomol. Soc. 18, 111-119

Bologna, M. A., Di Giulio, A. (2011) Biological and morphological adaptations in the pre-imaginal phases of the beetle family Meloidae. Atti Accad. Naz. Ital. .Entomol. Anno LIX, 141-152

Bologna, M.A., Pinto, J.D. (2001) Phylogenetic studies of Meloidae (Coleoptera), with emphasis on the evolution of phoresy. Syst. Entomol. 26, 33-72

Cameron, S.A., Ramírez, S. (2001) Nest architecture and nesting ecology of the orchid bee Eulaema meriana (Hymenoptera: Apinae: Euglossini). J. Kans. Entomol. Soc. 74, 142-165

Dodson, C.H. (1966) Ethology of some bees of the tribe Euglossini (Hymenoptera: Apidae). J. Kans. Entomol. Soc. 39, 607-629

Erickson, E.H., Enns, W.R., Werner, F.G. (1976) Bionomics of the bee-associated Meloidae (Coleoptera); bee and plant hosts of some Nearctic meloid beetles-a synopsis. Ann. Entomol. Soc. Am. 69, 959-970

Garófalo, C.A., Rozen Jr., J.G. (2001) Parasitic behavior of Exaerete smaragdina with descriptions of its mature oocyte and larval instars (Hymenoptera: Apidae: Euglossini). Am. Mus. Nov. 3349, 1-26

Garófalo, C.A., Camillo, E., Serrano, J.C. (2011) Reproductive aspects of Meloetyphlus fuscatus a meloid beetle cleptoparasite of the bee Eulaema nigrita (Hymenoptera, Apidae, Euglossini). Apidologie 42, 337-348

Horn, W. (1928) Meloetyphlus fuscatus . Entomol. Blätter 24, 88

Linsley, E.G., MacSwain, J.W., Michener, C.D. (1980) Nesting biology and associates of Melitoma (Hymenoptera, Anthophoridae). Univ. Calif. Publ. Entomol. 90, $1-45$

Nates-Parra, G., González, V.H. (2000) Notas sobre el nido de Eulaema polychroma (Hymenoptera: Apidae: Euglossini). Actual. Biol. (Medellin) 22, 83-90

Packer, L. (1987) The triungulin larva of Nemognatha (Pauronemognatha) punctulata LeConte (Coleoptera: Meloidae) with a description of the nest of its host-Megachile brevis pseudobrevis Say (Hymenoptera: Megachilidae). J. Kans. Entomol. Soc. 60, 280-287

Peruquetti, R.C., Campos, L.A.O. (1997) Aspectos da biologia de Euplusia violacea (Blanchard) (Hymenoptera, Apidae, Euglossini). Rev. Bras. Zool. 14, 91-97

Pinto, J.D., Bologna, M.A. (1999) The new world genera of Meloidae (Coleoptera): a key and synopsis. J. Nat. Hist. 33, 569-620

Rocha-Filho, L.C., Garófalo, C.A. (2013) Community ecology of euglossine bees in the coastal Atlantic Forest of São Paulo State. Brazil. J. Insect Sci. 13, 1-19

Santos, M.L., Garófalo, C.A. (1994) Nesting biology and nest re-use of Eulaema nigrita (Hymenoptera: Apidae: Euglossini). Insectes Soc. 41, 99-110

Saul-Gershenz, L.S., Millar, J.G. (2006) Phoretic nest parasites use sexual deception to obtain transport to their host's nest. Proc. Natl Acad. Sci 103 , 14039-14044

Selander, R.B. (1960) Bionomics, systematics, and phylogeny of Lytta, a genus of blister beetles (Coleoptera, Meloidae). Ill. Biol. Monogr. 28, 1-295 
Selander, R.B. (1965) The systematic position of Meloetyphlus, a genus of blind blister beetles (Coleoptera: Meloidae). J. Kans. Entomol. Soc. $38,45-55$

Selander, R.B. (1991) Meloidae (Tenebrionoidea). In: Stehr, F.W. (ed.) Immature insects. Kendall/Hunt, vol. 2, pp. 530-534. Dubuque, Iowa

Selander, R.B., Mathieu, J.M. (1964) The ontogeny of blister beetles (Coleoptera, Meloidae) I. A study of three species of the genus Pyrota. Ann. Entomol. Soc. Am. 57, 711-732

Vereecken, N.J., Mahé, G. (2007) Aggregations of the blister beetle Stenoria analis (Schaum) (Coleoptera: Meloidae) sexually deceive patrolling males of their host, the solitary bee Colletes hederae Schmidt \& Westrich (Hymenoptera: Colletidae). Ann. Soc. Ent. France. 43, 493-496 